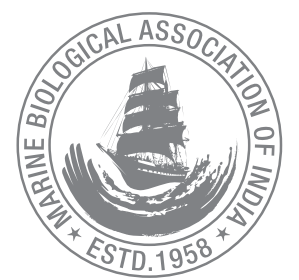

\title{
Fleet optimization of trawl fishery along southwest coast of India using surplus production model
}

\author{
T. M. Najmudeen*, T. V. Sathianandan and P. U. Zacharia \\ Central Marine Fisheries Research Institute, Ernakulam North P. O., Kochi-682018, Kerala, India. \\ *Correspondence e-mail: najmudeentm@yahoo.com
}

Received: 12 Sep 2014, Accepted: 05 Nov 2014, Published: 15 Nov 2014

Original Article

\begin{abstract}
The impact of trawl fisheries on the multi-species fishery resources, along the southwest coast of India, was studied by applying surplus production model and genetic algorithm approach using 23 years of time series data on catch and fishing effort during the period 1990-2012. The annual trawl landings varied from 0.282 million tonnes $(t)$ in 1990 to 0.570 million $t$ in 2012 with average annual landing of 0.357 million t. Though the effort in number of fishing units has been reduced from 0.756 million units in 1990 to 0.408 million in 2012, the effort in actual fishing hours has increased substantially (142\%) during the last two decades. The catch rate of high value groups such as large pelagics, penaeid prawns and cephalopods have gradually declined whereas low value groups such as small pelagics and miscellaneous groups have been caught in higher rate. The average biomass, yield, fishing mortality and fishing effort of the resources harvested by trawlers during the last three years were compared with the maximum sustainable yield (MSY), biomass at MSY level (BMSY), fishing mortality at MSY level (FMSY) and fishing effort corresponding to MSY (fMSY), which are estimated using genetic algorithm approach based on Schaefer's non-linear surplus production model. Assuming the last three years fishing effort as the current level of effort, the optimum level of exploitation was found marginally lower (99\%) than the current level of exploitation to keep the annual average yields just below MSY.
\end{abstract}

Keywords: Catch per hour, Genetic algorithm, MSY, Surplus production model, Trawl fishery.

\section{Introduction}

Trawl fishery is the most important among the various fishing methods in India and contributes about 52\% to the total marine fish production in the country. The estimated average annual fish catch from trawlers in India is about 2.037 million tonnes during 2012, of which, about $28 \%$ was contributed by the southwest coast alone (Anon, 2013). Trawl fishing activities in the country include single-day as well as multiday fishing. The extensive sweeping of sea bottom by the trawlers cause widespread damage to the marine biota and there is an urgent need for regulation in fishing for sustainable fish production (Devaraj and Vivekanandan, 1999). Trawl activities in many maritime countries are currently managed by input controls, which limit the fishing capacity of the vessels and gear used, indirectly controlling the amount of fish/prawns caught. Indian marine fisheries is a multi-species fishery comprising more than 800 species, of which, 200 are 
commercially important species of finfishes and shellfishes. The multi-species nature of the trawl fishery of the tropical seas surrounding Indian coast makes the development of an effective management strategy highly complex.

The southwest coast is the most important region in terms of marine fish production in India. The Arabian Sea in the west coast of India, is one of the most productive regions in the world oceans (Vivekanandan et al., 2005). Though the length of the south $\neg$ west coast has a span of $894 \mathrm{~km}$, which is only about $16 \%$ of the Indian coastline, the region contributed $35.1 \%$ (1.386 million tonnes) to the annual marine fish production of India during 2012. The potential yield of fish stocks along the southwest coast has been estimated by different studies (George et al., 1977; Alagaraja, 1989; Anon., 1991; Vijayakumaran, 2010). Estimates of MSY and optimum fleet size for the exploited Indian shelf fisheries was done by Kurup and Devaraj (2000) using simulation of the gearwise catch and effort data. In their model, the expected MSY values for the different fishing fleet in different states have been obtained by projecting the current average yield to the MSY. Sathianandan et al. (2008) estimated potential yield (PY) and maximum sustainable fleet size using time series data on marine fish landings and effort along the Kerala state during 1997-2007 and found that the number of trawlers and outboard ringseiners in operation in the state were more than the recommended maximum sustainable fleet size.

Standardization of optimum fleet size for the trawl fishery of the southwest region along with other management options based on MSY estimates is essential in order to provide benefits in terms of increased catches, increased profits, healthier fish stocks and also improved livelihoods for the small-scale artisanal fishers in the region. In order to address the above objectives, the present study was undertaken to analyse the impact of trawl fisheries on the multi species resource base of southwest coast of India, estimate the maximum sustainable yield and biomass of trawlable resources and corresponding efforts expended, using Schaefer's non-linear surplus production model, and to suggest necessary management options to manage the trawl fisheries of southwest coast of India at sustainable levels.

\section{Material and methods}

\section{Data and Analysis}

The data on trawl catch, fishing effort in hours of fishing and in number of fishing units for the period 1990-2012, collected by the Fishery Resource Assessment Division of Central Marine Fisheries Research Institute using stratified multi-stage random sampling method (Srinath et al., 2005),

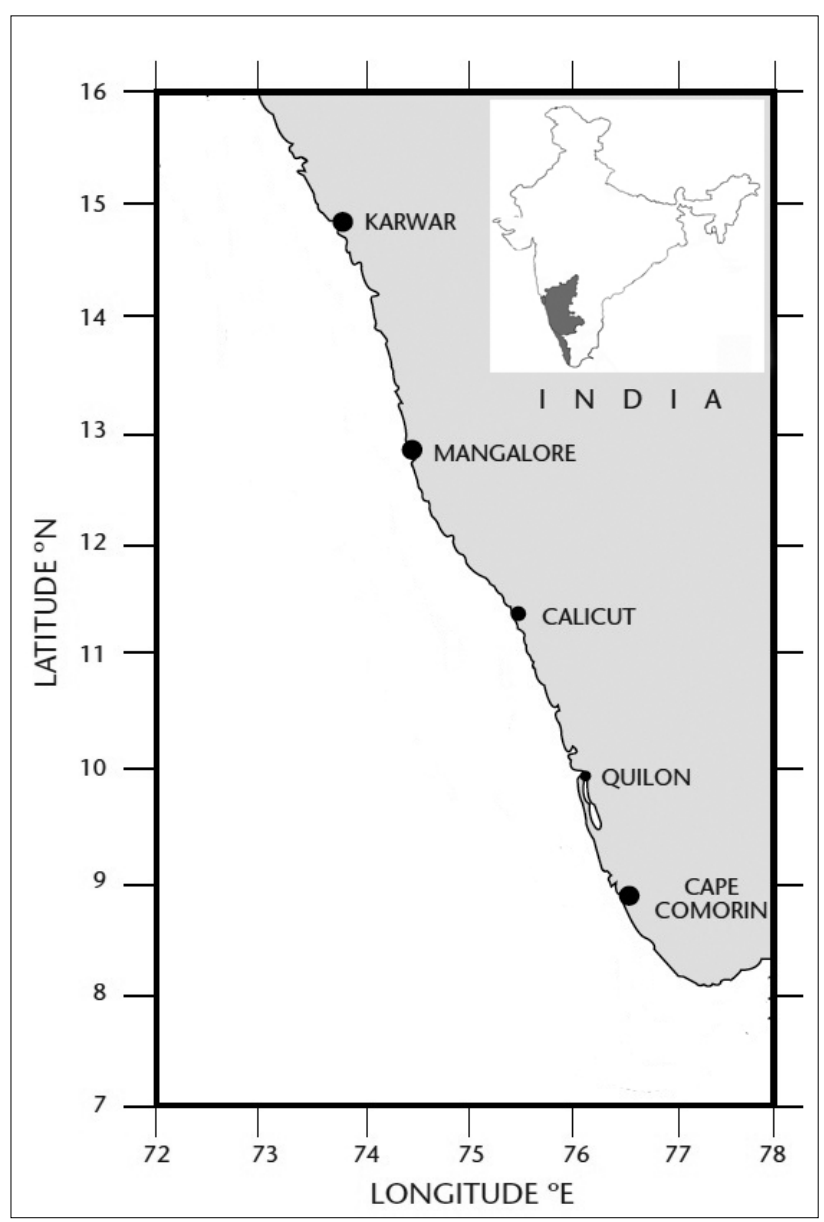

Fig. 1. Study area: southwest coast of India.

were used for the present model and subsequent analysis. The annual mechanized trawl catches of the region were grouped into major ecological groups or assemblages such as demersal finfishes, large pelagics, small pelagics, penaeid prawns, cephalopods and others to arrive at the structural change of the fishery resources over the study period. The southwest coast region of India extends from about $8^{\circ} \mathrm{N}$ to $15^{\circ} 30^{\prime} \mathrm{N}$ (Fig.1) with a coastline length of $894 \mathrm{~km}$, adjoining three maritime states, Kerala, Karnataka and Goa.

\section{The Model}

The basic surplus production model (Schaefer, 1954) is used for the estimation of biomass, fishing mortality and maximum sustainable yield of the trawlable resources along the southwest coast of India. The model is given by:

$\frac{d B_{t}}{d t}=r B_{t}\left(1-\frac{B_{t}}{K}\right)-F_{t} B_{t}$ 
The biomass in the above model is calculated as

$$
B_{t+1}=\left\{\begin{array}{ccc}
\frac{\alpha_{t} \exp \left(\alpha_{t}\right) B_{t}}{\alpha_{t}+\beta\left(\exp \left(\alpha_{t}\right)-1\right) B_{t}} & \text { when } \alpha_{t} \neq 0 \\
\frac{B_{t}}{1+\beta B_{t}} & \text { when } \alpha_{t}=0
\end{array} \text { for } t=1, \cdots, T\right.
$$

Where $\beta=\frac{r}{K} \quad, \quad \alpha_{t}=r-F_{t}$, and $F_{t}=q f_{t}$

Here, $F_{t}$ is the fishing mortality rate, $f_{t}$ fishing effort, $k$ carrying capacity, $r$ is the intrinsic rate of increase of the stock, $\mathrm{B}_{\mathrm{t}}$ biomass at time $\mathrm{t}$ (year), $\mathrm{q}$ is the catchablity coefficient

The estimates of maximum sustainable yield (MSY), biomass at MSY, fishing mortality and the fishing effort corresponding to MSY were estimated (Prager, 1994) as given below:

$$
M S Y=\frac{K r}{4} \quad B_{M S Y}=\frac{K}{2} \quad F_{M S Y}=\frac{r}{2} \quad f_{M S Y}=\frac{r}{2 q}
$$

The parameters of the model were estimated based on the genetic algorithm approach developed by Sathianandan and Jayasankar (2009) using time series data on catch and effort.

Genetic algorithm (GA) is a searching algorithm, based on the principle of evolution. It considers many points at each step in the searching process so that it does not converge to a local optimal solution. A solution in GA is an individual belonging to a population, possessing a character sequence or binary sequence defined as its chromosome (genotype). A fitness function is defined to evaluate the individuals and the one with highest fitness score is the best solution.

The population size for the Genetic Algorithm was fixed as 30 and the initial population was generated by creating chromosomes randomly. Initial estimates of $B, K, r$ and $q$ were obtained by following the procedure given by Wang (2002) and an individual corresponding to these estimates was created and included in the initial population. The process of evolution takes place by generating new individuals for the next generation from the existing generation through the application of selection, crossover and mutation. New generations were formed one after another and individuals were evaluated using the fitness function.

\section{Results and discussion}

\section{Resource characteristics of trawl fisheries of southwest coast}

The average annual landings of mechanised trawls along the southwest coast of India was 0.357 million tonnes during 1990-2012 period. While the effort in terms of fishing units has been reduced from 0.756 million in 1990 to 0.408 million in 2012 , the effort in terms of actual fishing hours expended has

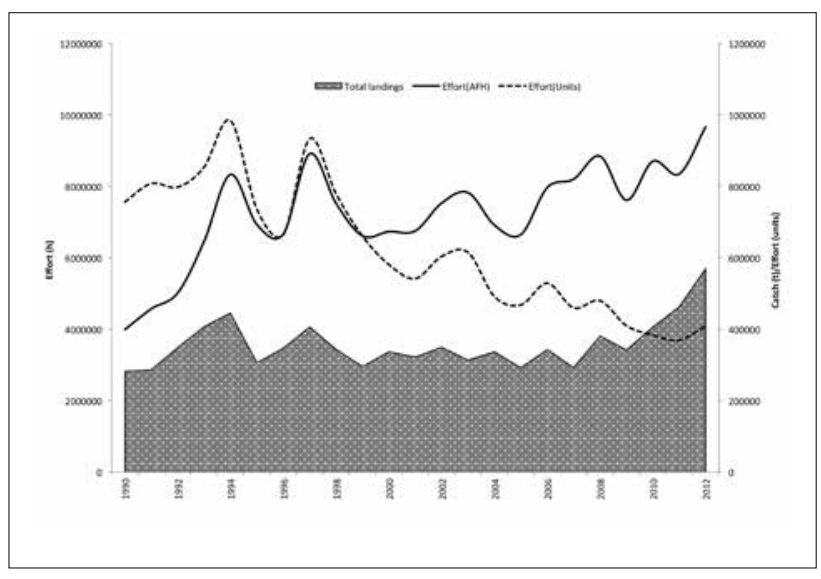

Fig. 2. Trends in catch and effort of mechanized trawl operated along south-west coast of India during 1990-2012

increased substantially (142\%) during the last two decades (Fig. 2). This is primarily due to the conversion of many of the single day trawlers to multi-day trawlers, which spend 3-8 days for fishing in one trip. It is noteworthy that, from the late 1990s, the bottom trawlers have extended the fishing grounds along the west coast of India up to $400 \mathrm{~m}$ depth in pursuit of deepsea prawns and other deepsea resources (Rajan et al., 2001). The increase in fishing activity could also be discerned from the increase in the number of mechanized boats by 7.4 times along the Indian coast (Vivekanandan et al., 2005).

The demersal finfish assemblage dominated in the catch $(37 \%)$ of trawlers, comprising mostly threadfin breams, soles, lizardfishes and croakers in their order of abundance. This was followed by small pelagics (23\%), penaeid prawns (13\%) and cephalopods (11\%). The small pelagic assemblage includes scads, other carangids, anchovies and Indian mackerel. The large pelagics group is dominated by barracudas, seerfishes and tunas. The crustaceans other than penaeid prawns consisted mainly of crabs, non penaeid prawns and lobsters in order of abundance. The others, which contribute to $16 \%$ of the total annual average landings of trawl includes penaeid prawns and other crustaceans (Fig. 3). While the catch per 


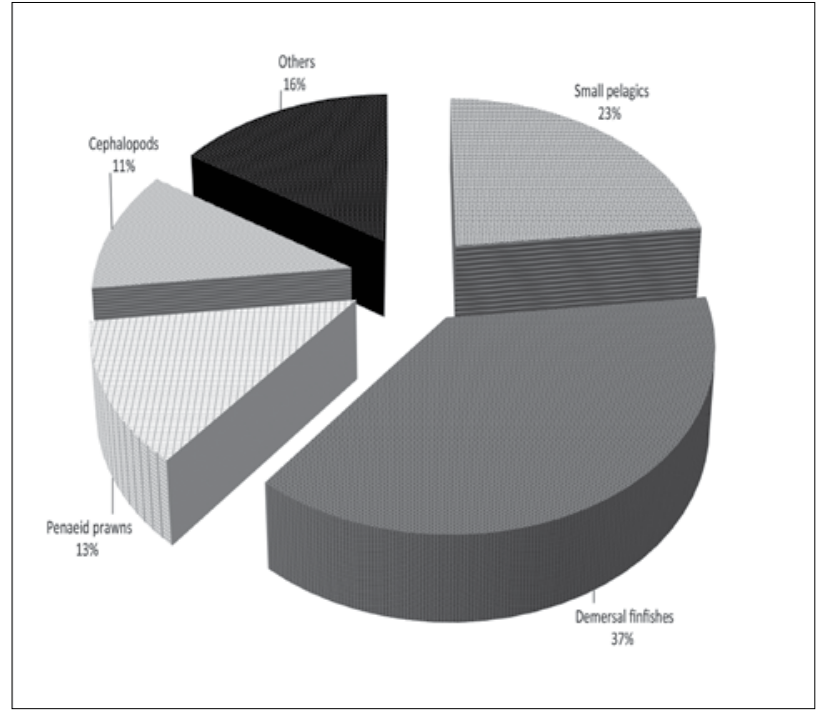

Fig. 3. Composition of various resource groups in the trawl landings of southwest coast India during 1990-2012

hour ( $\mathrm{CPH}$ ) of the low value small pelagics and some of the demersal finfishes has increased steadily after 2007, the CPH of high value resources such as penaeid prawns and cephalopods have been declining gradually since 1990 (Fig. 4). There is a notable shift in the resources exploited by trawlers from high value groups to low value resources, which substantiates the fishing down the food web concept noticed by Vivekanandan et al. (2005). They conclude that, from the 1970s, the trawl fishery of India targeted the low trophic level (2.51) penaeid prawns, which attracted export market and this market-driven fishery for the penaeid prawns became deliberate choice of fishing down the food web along the Indian coast. Along with penaeid prawns, a large assemblage of low value finfishes was caught in the trawlers along the coast.

The analysis of catch and effort data reveal that, during 19902012, the catch per unit effort increases in tune with the increase in catch as well as effort in terms of fishing units (Fig. 5). This is primarily due to the increase in the fishing hours expended by the trawlers by operating more multiday trips. The average hours per trip of a multiday trawler operating along the region are 30 and that of the single day trawlers is only 7 hours per trip. However, the catch per unit hour of the trawler was low whenever the effort in terms of actual fishing hour is higher (Fig. 6). This implies the need for management interventions to reduce the effort and this situation prompted us to apply the Shaefer's surplus production model to estimate the MSY and thereby to suggest the optimum effort in hours for the trawlers operating along the region. The catch rates of high value groups such as large pelagics and penaeid prawns were also low whenever the effort is high.

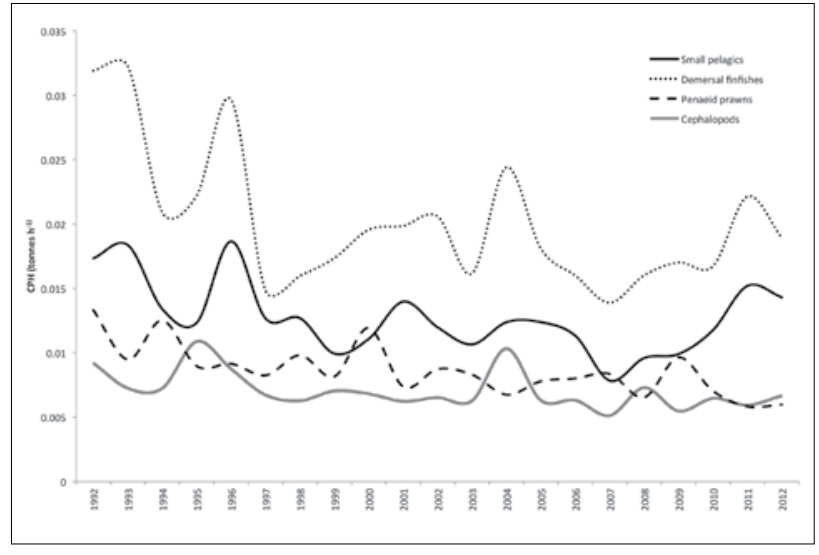

Fig. 4. The trend in catch rate of various resource groups landed by trawlers along the south west coast of India during 1990-2012

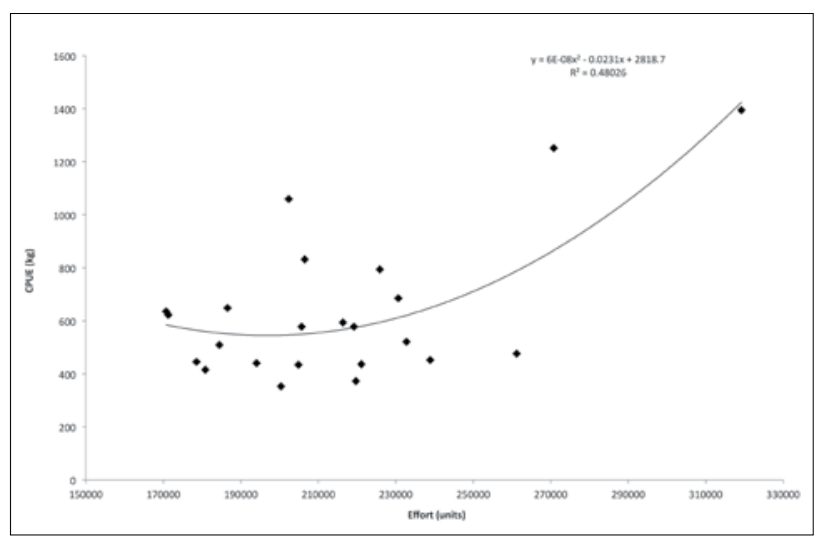

Fig. 5. Catch per unit effort against effort in fishing units of trawlers along southwest coast of India during 1990-2012

\section{The model parameters}

The estimated model parameters using Genetic Algorithm approach for trawlers along the southwest coast of India are given in Table 1. The fishing effort during 1990 was 3.99 million hours, which registered threefold increase during the 23 year period and reached the highest of 9.66 million tonnes in 2012. The fishing effort at MSY level was estimated at 8.59 million hours only, which is $11 \%$ lower than the present fishing effort expended during 2012. The initial biomass (B0) is estimated at 0.546 million tonnes, which was the biomass of the trawlable resources during 1990 along the southwest coast of India. At the end of 23 year period, the biomass is estimated at 0.325 million tonnes, registering a decrease of $40 \%$. The carrying capacity of the region is estimated at 0.62 million tonnes. The intrinsic growth rate of the fishery $(r)$ was 2.374 and the catchability coefficient $q$ was worked out at 0.000000134 . Fig. 7 and 8 show the simulated yield and biomass for trawl fishery in southwest coast of India during 1990-2012. 


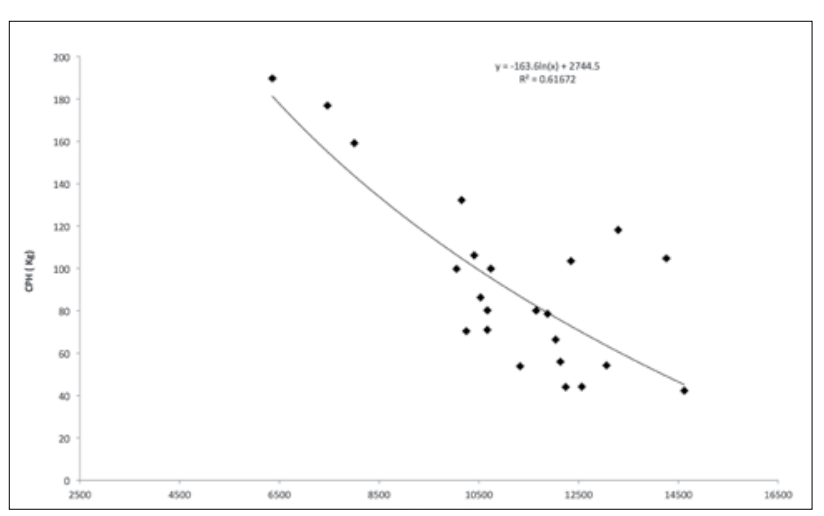

Fig. 6. Catch per unit hour against effort in hours of trawlers along southwest coast of India during 1990-2012

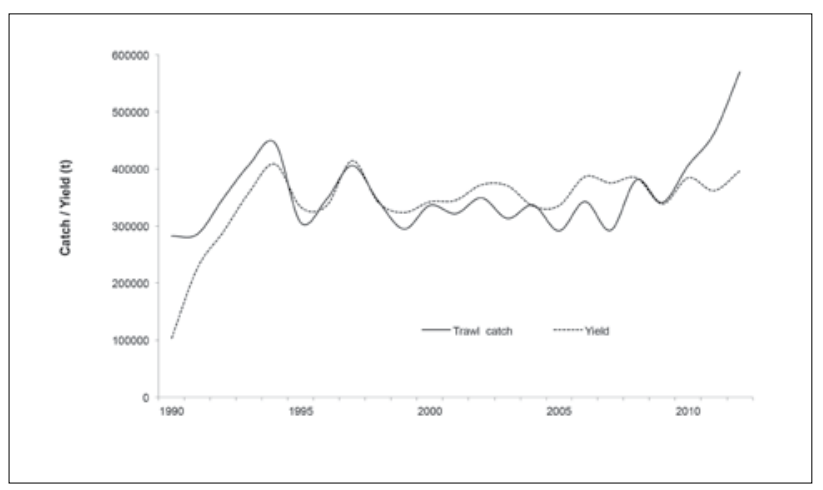

Fig. 7. Surplus production model fitted to the trawl fisheries of southwest coast of India

\section{Maximum sustainable yield}

MSY is the recommended yield that can be harvested from the total biomass without affecting the sustainability of the fishery. Potential yield is the level at which the resource can be harvested at its MSY level. Hence for the validation of potential yield, periodical estimation of MSY is a prerequisite. The total exploitable resources estimated by George et al. (1977) for the 50-200 m depth zone off southwest coast of India was 0.325 million tonnes. The present estimate of MSY for trawlable resources using Genetic Algorithm approach of optimization is 0.366 million tonnes (Table 1), which is marginally higher than the estimates obtained by George et al. (1977). The higher MSY estimates for the present model is mainly due to the use of data on catch and effort of the trawlers, which are operating beyond the depth zone of 200 $m$ along the southwest coast. Sudarsan et al. (1988) estimated a potential primarily based on trawl surveys from $50-100 \mathrm{~m}$ depth zone as 0.140 t only.

The potential for the shelf and slope beyond $50 \mathrm{~m}$ depth zone estimated by the Working Group on Revalidation (Anon, 1991) was only 0.112 million tonnes for southwest coast of
India. However, Goswami and Shrivastava (1996), based on large fishing coverage using trawlers, mostly above $50 \mathrm{~m}$ depth zone, obtained an estimate of 0.260 million tonnes as the potential yield of the region. This implies that the present estimate of MSY is higher than any of the estimates mentioned, as the catch and effort data used for the surplus production model was emanated from the depth zone beyond $200 \mathrm{~m}$ or even more. As per a recent estimate by the committee led by Vijayakumaran (Anon 2011), the estimated potential yield from southwest region was 1.2 million tonnes, of which 0.42 million tonnes (35\%) was expected to be from trawlers.

Table 1. Estimates of model parameters using GA

\begin{tabular}{ll}
\hline Parameters & Value \\
\hline $\mathrm{B}(0)(\mathrm{t})$ & 545629 \\
\hline $\mathrm{K}(\mathrm{t})$ & 616675 \\
\hline $\mathrm{r}$ & 2.3743 \\
\hline $\mathrm{q}$ & 0.000000134 \\
\hline MSY (t) & $3,66,049$ \\
\hline BMSY (t) & $3,08,338$ \\
\hline FMSY & 1.187 \\
\hline fMSY (hrs) & $88,59,481$ \\
\hline Present Yield (t) & $4,79,359$ \\
\hline Present effort (hrs) & $89,03,950$ \\
\hline
\end{tabular}

The results indicate that the catch per unit effort (CPUE) of the trawlable resources has been increasing steadily over the last 23 year period. However the CPH (catch per hour of operation) of trawlers in the region has been declining significantly since 1990. As the effort expended are variable from year to year, the average effort in hours for the last three years have been taken as the present effort and the average catch for the last three years were taken as the present yield. The average biomass, yield, fishing mortality and fishing effort of the resources harvested by trawl during the last three years were compared with the maximum sustainable yield (MSY), biomass at MSY level $\left(B_{\text {MSY }}\right)$, fishing mortality at MSY level $\left(F_{\text {MSY }}\right)$ and fishing effort corresponding to MSY ( $\left.f_{\text {MSY }}\right)$ estimated using genetic algorithm approach based on Schaefer's nonlinear surplus production model. Assuming the last three years fishing effort as the current level of effort, the optimum level of exploitation was found marginally lower (99\%) than the current level of exploitation to keep the annual average yields just below MSY.

The number of trawlers registered as per the All India Marine Fisheries Census, 2010, conducted by the Central Marine Fisheries Research Institute (CMFRI, 2012) along the southwest 


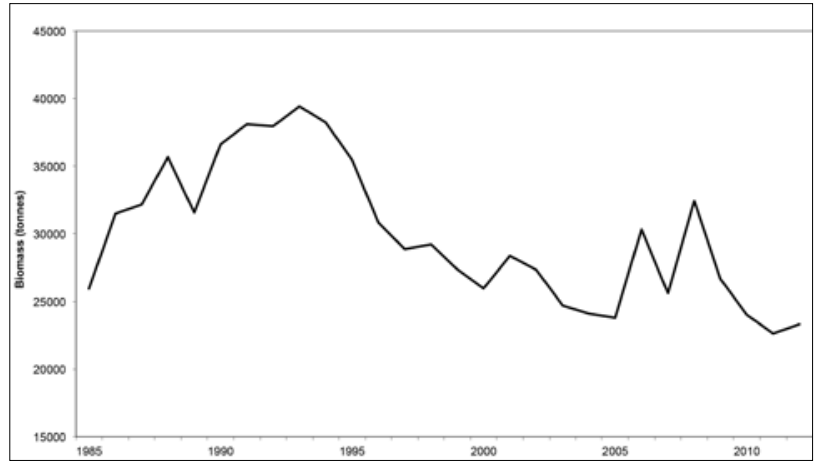

Fig.8. Estimated annual biomass of trawlable resources along the southwest coast of India during 1990-2012

coast of India was 7,359, of which 3,678 were operating along the Kerala coast alone and the rest being landed in Karnataka and Goa coasts (Table 2). Using the data on the effort expended for multi-day trawlers and single day trawlers, available at the Fishery Resource Assessment Division of CMFRI, the fMSY estimated using Genetic Algorithm method corresponding to the MSY level was allocated separately for multi-day as well as single day trawlers. The optimum fleet size, which can exploit the trawlable resources at MSY level, along southwest coast of India was calculated based on the hours of operation of both multiday trawlers and single day trawlers separately (Table 3). Thus, using Genetic Algorithm approach of optimization as a best tool and based on the Schaefer's non-linear surplus production model, the optimum fleet size for the region was estimated at 4,056 multi-day trawlers and 969 single day trawlers to sustain the trawl fishery of southwest coast of India. Although some of the

Table 2. Existing vs optimum trawl fleet along southwest coast of India

\begin{tabular}{ll}
\hline Parameters & Value \\
\hline Kerala & 3678 \\
\hline Karnataka & 2847 \\
\hline Goa & 834 \\
\hline Total SW coast & $7359^{*}$ \\
\hline Optimum fleet & 7211 \\
\hline
\end{tabular}

*Source: Marine Fisheries Census 2010

Table 3. Optimum fleet size for various types of trawlers along southwest coast of India

\begin{tabular}{lll}
\hline Fleet & Multiday trawlers & Single day trawlers \\
\hline $\begin{array}{l}\text { Maximum hours of } \\
\text { operation }\end{array}$ & $7,30,0212$ & $1,559,269$ \\
\hline Trips per year & 60 & 230 \\
\hline Hours per trip & 30 & 7 \\
\hline Optimum fleet size & 4056 & 969 \\
\hline $\mathrm{Z}^{\star \star}$ Assuming current effort as avg. of last 3 years
\end{tabular}

earlier investigations addressed the occurrence, availability and abundance of major demersal and pelagic fishery resources in the nonconventional fishing grounds in the EEZ of southern India (Silas, 1969; Oommen, 1974; James et al., 1987; Sudarsan et al., 1988; James and Pillai, 1989), there is no concerted effort to standardize the optimum fleet size for a specific gear, based on the MSY estimates. The present model using $\mathrm{GA}$ is a novel and more predictable approach which can be applied all along the Indian coast to optimize the fishery thereby reducing the fishing pressure in order to sustain the trawl fishery of the country.

\section{Acknowledgements}

The authors express their deep sense of gratitude to the Director, CMFRI for constant encouragements and for providing necessary facilities to conduct the study.

\section{References}

Alagaraja, K. 1989. A brief appraisal of marine fisheries in India. CMFRI Bulletin 44: 36-41.

Anon. 1991. Report of the working group on revalidation of the potential marine fisheries resources of the Exclusive Economic Zone of India, (MPEDA, Cochin), 57 pp.

Anon. 2011. Report of the working group for revalidating the potential of fishing resources in the Indian EEZ. Department of Animal Husbandary, Dairying and fisheries, Minstry of agriculture, New Delhi, $69 \mathrm{pp}$.

Anon. 2013. Annual report 201-13. Central Marine Fisheries Research Institute, Kochi, $185 \mathrm{pp}$.

CMFRI. 2012. Marine Fisheries Census 2010 Part I - India. Ministry of Agriculture, KrishiBhavan, New Delhi and CMFRI, Kochi, 98 pp.

Devaraj, M. and E. Vivekanandan. 1999. Marine fisheries of India: challenges and opportunities. Curr. Sci. 76, 315-332.

George, P. C, B. T. Antony Raja, K. C. George. 1977. Fishery resources of the Indian Economic Zone, (Marine Products Export Development Authority, Cochin).

Goswamy, S. C. and Y. Shrivastava. 1996. Zooplankton standing stock, community structure and diversity in the northern Arabian Sea, In: V. K. Pillai, S. A. H. Abidi, V. Ravindran, K. K. Balachandran and V. V. Agadi (Eds.), Proceedings of the Second Workshop on Scientific Results of FORV Sagar Sampada, Department of Ocean Development, New Delhi, p. 127-137.

James, P. S. B.R., K. Alagarswamy, K. V. N. Rao, M. S. Muthu, M. S. Rajagopalan, K. Alagaraja and C. Mukundan. 1987. Potential Marine fishery resources of India, CMFRI Sp. Pub. 30: 44- 74.

James, P. S. B. R. and V. N. Pillai. 1989. Fishable concentrations of fishes and crustaceans in the offshore and deep sea areas of the Indian Exclusive Economic Zone based on observations made onboard FORVSagar Sampada, In: K.J. Mathew (Ed.), Proc. First Workshop Scient. Result. FORV Sagar Sampada, CMFRI, Cochin, p. 201-213.

Kurup K. N. and M. Devaraj, 2000. Estimates Of Optimum Fleet Size For The Exploited Indian Shelf Fisheries. Mar. Fish. Inf. Ser. T\& E Series, 165: 2-11

Oommen, V.P. 1974. A brief account of the topography and fishery potential of the south west coast of India, Mahasagar - Bull. Natn. Inst. Oceanogr. 7(1 \& 2): 33 39

Prager, M. H. 1994. A suite of extensions to a nonequilibrium surplus-production model. Fish. B. NOAA, 92(2): 374- 389.

Rajan, K. N., G. Nandakumar and K. Chellappan. 2001. Innovative exploitation of deepsea crustaceans along the Kerala coast. Mar.Fish. Inf. Serv. T \& E Ser., 168: $1-11$.

Sathianandan, T. V. and J., Jayasankar, 2009 Managing marine fishery in Kerala through simulation using surplus production model, genetic algorithm and spectral methods. Indian J. Fish., 56(3): 163-168.

Sathianandan, T. V., J. Jayasankar, E. Vivekanandan, R. Narayankumar and N.G.K. Pillai. 2008. Estimates on potential yield and maximum sustainable fleet size for marine fisheries in Kerala J. Mar. Biol. Ass. India, 50 (2): 196 - 201

Schaefer, M.B. 1954. Some aspects of the dynamics of populations important to the management of commercial marine fisheries. Bull. Inter-Am. Trop. Tuna Comm., 
T. M. Najmudeen et al.

1(2): 27-56.

Silas, E. G. 1969. Exploratory fishing by $K$ Varuna, CMFRI Bull. 12: 1-86

Srinath, M., Somy Kuriakose and K.G. Mini. 2005. Methodology for the estimation of marine fish landings in India. CMFRI Special Publication, 86, $57 \mathrm{pp}$.

Sudarsan, D., T. E. Sivaprakasam, V. S. Somavanshi, M. E. John, K. N. V. Nair and Antony Joseph. 1988. An appraisal of the marine fishery resources of the Indian Exclusive Economic Zone, Bull Fish. Surv. India, 18: 1-85.
Vivekanandan E., M. Srinath and Somy Kuriakose. 2005. Fishing the marine food web along the Indian coast. Fish. Res. 72: 241-252

Wang, C. H. 2002. Estimating the population parameters $r, q$, and $K$ based on surplus production model. 15th meeting of the Standing Committee on Tuna and Billfish, July 22-27, 2002, Honolulu, Hawaii., SCTB-15 working paper, ALB-7, 19pp. URL: http://www.spc.org.nc/OceanFish/Html/SCTB/ SCTB17/MGW-2.pdf. 